\title{
Clinical outcomes in ALK-rearranged lung adenocarcinomas according to $A L K$ fusion variants
}

\author{
Yoon Jin Cha ${ }^{1}$, Hye Ryun Kim ${ }^{2}$ and Hyo Sup Shim ${ }^{3^{*}}$ (1)
}

\begin{abstract}
Background: Clinical outcomes of anaplastic lymphoma kinase (ALK)-rearranged non-small cell lung cancer according to $A L K$ fusion variants are not clear. We aimed to investigate the prevalence of $A L K$ fusion variants and to compare clinical outcomes according to ALK fusion variants.

Methods: A retrospective analysis was conducted on patients with advanced ALK-rearranged adenocarcinoma treated with chemotherapy and ALK inhibitors. ALK rearrangement was identified by fluorescence in situ hybridization and confirmed by immunohistochemistry. Peptide nucleic acid-mediated quantitative polymerase chain reaction assays, designed to detect 28 types of echinoderm microtubule-associated protein-like 4 (EML)-ALK rearrangements, were performed. Clinicopathological analysis and treatment outcomes with platinum-based chemotherapy, pemetrexed therapy, and ALK inhibitors —including crizotinib and ceritinib-were evaluated.

Results: A total of 52 patients with ALK-rearranged lung adenocarcinoma were enrolled. EML4-ALK variant 1 (v1) was the most common variant (38.5\%) followed by the non-EML4 variant (36.5\%), EML4-ALKvariant 3a/b (19.2\%), and EML4-ALK variant 2 (5.8\%). No clinicopathological distinction was found between the different ALK fusion variants. Treatment response rates for each therapeutic agent did not differ according to ALK fusion variant. However, EML4 variants, especially $v 1$, showed significantly longer progression-free survival (PFS) on pemetrexed treatment than did non-EML4 variants (median 31.1 months versus 5.7 months, $P=0.003$ ). PFS with platinum-based chemotherapy and ALK inhibitors did not differ according to ALK fusion variant. Multivariate survival analysis using Cox's regression model revealed $\mathrm{v} 1$ as the only predictive factor for prolonged PFS on pemetrexed.
\end{abstract}

Conclusions: Among ALK fusion variants, $\mathrm{v} 1$ is the most common subtype. It showed superior progression-free survival on pemetrexed than did non-EML4 variants. No survival difference was demonstrated between variants treated with crizotinib or ceritinib.

Keywords: Non-small cell lung cancer, Anaplastic lymphoma kinase, EML4-ALK fusion, Pemetrexed, Anaplastic lymphoma kinase inhibitor

\section{Background}

Anaplastic lymphoma kinase $(A L K)$ rearrangements, found in approximately $5 \%$ of non-small cell lung cancers (NSCLCs), are relatively rare genetic alterations compared with epidermal growth factor receptor (EGFR)

\footnotetext{
*Correspondence: shimhs@yuhs.ac

${ }^{3}$ Department of Pathology, Severance Hospital, Yonsei University College of Medicine, 50-1 Yonsei-ro, Seodaemun-gu, Seoul 03722, South Korea Full list of author information is available at the end of the article
}

or KRAS mutations [1]. Soda et al. identified the echinoderm microtubule-associated protein-like 4 (EML4)-ALK fusion gene, and reported its transforming activity and potential as a therapeutic target in NSCLCs [2]. Subsequently, following reports of dramatic therapeutic effects of crizotinib on $A L K$-rearranged NSCLCs [3, 4], a number of studies on the clinicopathologic characteristics of $A L K$-rearranged NSCLC have been conducted [5-8]. Currently, the fluorescence in situ hybridization (FISH) method is considered the gold standard for 
establishment of $A L K$-rearrangement positivity. In addition, immunohistochemistry (IHC) for ALK protein is known to have high sensitivity and specificity for recognition of $A L K$ rearrangements and is strongly correlated with FISH results $[9,10]$. However, FISH and IHC cannot specify the different variants or fusion gene partners of the $A L K$ gene, which can be identified by real time-polymerase chain reaction (RT-PCR) or next-generation sequencing technology. Crizotinib is effective for NSCLC patients harboring ALK rearrangements ( $60 \%$ of patients achieve an objective response) but almost all experience disease progression after $8-11$ months $[3,11$, 12 ]. We hypothesized that different $A L K$ fusion variants would lead to different treatment responses. In the present study, we investigated the prevalence of $A L K$ fusion partners in NSCLCs, and explored whether the efficacy of therapeutic agents differs according to $A L K$ fusion variant.

\section{Methods}

A retrospective analysis was conducted on patients with advanced $A L K$-rearranged adenocarcinoma treated with chemotherapy and ALK inhibitors. This retrospective study was approved by the Institutional Review Board of Severance Hospital (No. 4-2015-0926).

\section{Clinicopathologic analysis}

The following clinicopathologic parameters were recorded: age, sex, smoking status [never smokers, former smokers (quit smoking $>1$ year before diagnosis), and current smokers], pack-year smoking history (defined as the number of cigarette packs smoked per day multiplied by the number of years of smoking), sites of metastasis, and pathological tumor stage at diagnosis. For histological analysis, intra- and/or extracellular mucin, $A L K$-related growth patterns including cribriform and solid signet ring cells, features of nuclei, and psammomatous calcification were examined. All samples were reviewed by experienced pulmonary pathologists (Y.J.C. and H.S.S.). Treatment methods, treatment responses, overall survival, and progression-free survival (PFS) were assessed. Tumor response was determined according to Response Evaluation Criteria in Solid Tumors, version $1.1[13]$.

\section{EGFR and KRAS mutation analysis}

To determine the EGFR and KRAS mutation status, DNA was extracted from formalin-fixed, paraffin-embedded (FFPE) tissues using the DNeasy Isolation Kit (Qiagen, Valencia, CA, USA), according to the manufacturer's instructions. For the EGFR gene, direct DNA sequencing of exons $18-21$ was performed using the PNA Clamp ${ }^{\mathrm{TM}}$
EGFR Mutation Detection Kit (PANAGENE, Daejeon, Korea). For the KRAS gene, direct DNA sequencing of codons 12 and 13 was performed. Each tumor was classified as positive or negative for a mutation after comparison with the wild-type gene sequence.

\section{ALK fluorescence in situ hybridization and immunohistochemistry}

To identify $A L K$ rearrangements, FISH was performed using a break-apart $A L K$ probe (Vysis LSI Dual Color, Break Apart Rearrangement Probe; Abbott Molecular, Abbot Park, IL, USA). ALK rearrangement was scored as positive when $>15 \%$ of tumor cells displayed split or isolated signals containing a kinase domain. IHC was performed using an ALK antibody (rabbit monoclonal, clone D5F3, Cell Signaling Technology, Danvers, MA, USA) and Ventana automated immunostainer BenchMark XT (Ventana Medical Systems, Tucson, AZ, USA), as previously described [14].

\section{RNA extraction and CDNA synthesis}

Total RNA was extracted using the PureLink ${ }^{\mathrm{TM}}$ FFPE Total RNA Isolation Kit (Invitrogen Carlsbad, CA, USA) with the following protocol modifications. The resulting RNA was eluted in $50 \mu \mathrm{L}$ of elution buffer. The concentration and purity of the extracted RNA were determined by spectrophotometry. The extracted RNA was stored at $-80{ }^{\circ} \mathrm{C}$ until required. We used $250 \mathrm{ng}$ of total RNA to generate cDNA using the Super Script VILO cDNA synthesis kit (Invitrogen).

\section{PNA-mediated qPCR assay for EML4-ALK screening and genotyping}

EML4-ALK fusion RNA was detected using the PANA $\mathrm{qPCR}^{\mathrm{TM}}$ EML4-ALK fusion gene detection Screening and Genotyping kit (PANAGENE, Daejeon, Korea), designed to detect 28 known $A L K$ rearrangements. Screening for and genotyping of 12 $E M L 4-A L K$ fusions was performed, including: E6;A19, E6;A20, E6ins33;A20(3ea), E6;ins18A20, E13;A20(5ea), E13;ins69A20(2ea), E20;A20(2ea), E20;ins18A20(2ea), E14ins11;del49A20(2ea), E14;del14A20, E14;del38A20, E2;A20, E2;ins117A20, E17;ins30A20, E17ins61;ins34A20, E17ins65;A20, E17;ins68A20, and E17del58;ins39A20. Reverse transcription and RT-PCR were performed in a CFX96 RT-PCR detection system (BIO-RAD, Foster city, CA, USA) under the following conditions: $2 \mathrm{~min}$ at $50{ }^{\circ} \mathrm{C}, 15 \mathrm{~min}$ at $95^{\circ} \mathrm{C}$ and 5 cycles of $10 \mathrm{~s}$ at $95^{\circ} \mathrm{C}, 30 \mathrm{~s}$ at $58^{\circ} \mathrm{C}$ and 45 cycles of $10 \mathrm{~s}$ at $95^{\circ} \mathrm{C}$, and $30 \mathrm{~s}$ at $58^{\circ} \mathrm{C}$ and $15 \mathrm{~s}$ at $72{ }^{\circ} \mathrm{C}$. A positive result was defined as a threshold cycle $(\mathrm{Ct})$ value $<40$, and a positive internal control was defined as a $\mathrm{Ct}$ value $<36$. A result was regarded as invalid 
if the assays for $E M L 4-A L K$ fusion gene and internal control showed simultaneous negative results. When invalid results were obtained, the assay was repeated using the newly synthesized cDNA. The assay result was interpreted as positive for EML4-ALK according to the manufacturer's instructions.

\section{Statistical analysis}

Clinicopathologic parameters were compared using the Chi square (for categorical parameters) and Mann-Whitney $U$ (for continuous parameters) tests. Survival was evaluated using the Kaplan-Meier method, and statistical differences in survival times were determined using the log-rank test. A Cox proportional hazards model was used to assess risk factors for PFS of each therapeutic agent. Statistical analyses were performed using SPSS 19.0 (SPSS Inc. Chicago, IL, USA), and a $P$ value $<0.05$ was considered significant.

\section{Results}

\section{Patient selection}

Between March 2000 and February 2015, ALK-rearrangement was confirmed in 76 patients at our institution; all had adenocarcinomas. Results of RT-PCR analysis for $A L K$ fusion partners were available for 52 of the 76 patients. These 52 patients were included: 19 were diagnosed by transbronchial lung biopsy or fiber optic bronchoscopy biopsy of the primary lung tumor, 6 by endobronchial ultrasound lymph node biopsy, 16 by lobectomy or wedge resection of the primary lung tumor, 5 by pleural biopsy, and 5 by biopsy of distant metastatic lesions.

\section{Clinicopathologic characteristics and ALK fusion variants}

Patients' clinicopathologic characteristics are summarized in Table 1 . The median age was 52 (range, 31-76) years and $23(44.2 \%)$ patients were male. Mean follow-up period was $43.4 \pm 7.1$ months (range, 2.4-347.0). Thirtyfive $(67.3 \%)$ were never smokers, $6(11.5 \%)$ were former smokers, and 11 (21.2\%) were current smokers. In terms of pathologic stage, 5.8 and $94.2 \%$ of cases were stage IIIB and stage IV, respectively, at study start. Twenty-eight $(53.8 \%)$ patients had lung or pleural metastasis (M1a), and $35(67.3 \%)$ had distant metastasis (M1b) (Additional file 1: Table S1). The most common site of distant metastasis was the brain $(N=23,44.2 \%)$. The EML4-ALK variant 1 (v1) was the most common $(N=20,38.5 \%)$, followed by the non-EML4 variant $(N=19,36.5 \%)$, EML4-ALK variant $3 a / b(\mathrm{v} 3 \mathrm{a} / \mathrm{b})(N=10,19.2 \%)$, and EML4-ALK variant 2 (v2) $(N=3,5.8 \%)$ (Fig. 1$)$.

Among the $A L K$ fusion variants, tumors with $E M L 4$ $A L K$ variants showed more frequent lung and/or pleural involvement without distant metastasis compared with the non-EML4 variants $(P=0.015)$. Among the $22 E M L 4$ variant tumors with lung and/or pleural involvement, the majority were $\mathrm{v} 1(N=13,65.0 \%$ of $\mathrm{v} 1)$ and $\mathrm{v} 3 \mathrm{a} / \mathrm{b}(N=8$, $80.0 \%$ of v3a/b). Other clinicopathologic parameters and histologic features did not differ according to $A L K$ fusion variant.

Most patients received platinum-based chemotherapy or pemetrexed therapy as first-line chemotherapy, before receiving crizotinib or ceritinib. Single-agent pemetrexed, EGFR tyrosine kinase inhibitors (TKIs), and single-agent platinum therapy were used as second-line or further lines of therapy. Patient treatment history before ALK inhibitor use is summarized in Additional file 1: Table S2.

\section{Efficacy of chemotherapy regimens and treatment response, according to ALK fusion partners}

Forty patients (76.9\%) received first-line platinum-based chemotherapy, with partial response (PR) in 10 (25.0\%), stable disease (SD) in 20 (50.0\%), and progressive disease (PD) in $10(25.0 \%)$. With regard to pemetrexed, 35 patients $(67.3 \%)$ received pemetrexed in any line of treatment: 7 (20.0\%), 25 (71.4\%), and 3 (8.6\%) patients showed PR, SD, and PD, respectively. There were no significant differences in objective response rate (ORR) or disease control rate (DCR) with platinum-based chemotherapy or pemetrexed, according to $A L K$ fusion variant.

Overall, 37 patients received ALK inhibitors, including crizotinib $(N=32,61.5 \%)$, ceritinib $(N=14,26.9 \%)$, and alectinib $(N=2,3.8 \%)$. ALK inhibitors were administered as second- or further-line therapy in most patients, except for 8 patients who received crizotinib $(N=7)$ and ceritinib $(N=1)$ as first-line therapy. Five patients (two $\mathrm{v} 1$ and three $\mathrm{v} 3 \mathrm{a} / \mathrm{b}$ ), who received crizotinib showed PD while most patients showed at least SD and PR to ALK TKI treatment. Overall, the ORR was $53.1 \%$ with crizotinib and $57.1 \%$ with ceritinib. Treatment response rates to ALK inhibitors did not differ according to $A L K$ fusion variant (Table 2).

A 42 year-old woman, who harbored a v2 variant, showed complete response (CR) to ceritinib. Her brief clinical history and detailed histologic features are summarized in Additional file 1: Fig. S1.

\section{Progression-free survival with each therapeutic agent, according to ALK fusion variant}

In patients who received first-line platinum-based chemotherapy, there was no significant difference in PFS according to $A L K$ fusion variant (Fig. 2). With regard to pemetrexed, EML4-ALK fusion variants showed significantly superior PFS compared to non-EML4 variants (Fig. 3a). When further analyzing the subtypes of EML4$A L K$ variants, v1 showed significantly better PFS than did the others (Fig. 3b). No significant difference according to 
Table 1 Clinicopathologic characteristics and histological analysis

\begin{tabular}{|c|c|c|c|c|}
\hline & Total $(N=52)$ & EML4 variants $(N=33)$ & Non-EML4 variants $(N=19)$ & $P$ value \\
\hline \multicolumn{5}{|l|}{ Clinicopathologic parameters } \\
\hline Age, median (range) & $52(31-76)$ & $50(31-76)$ & $55(32-70)$ & 0.227 \\
\hline Women (\%) & $29(55.8)$ & $21(63.6)$ & $8(42.1)$ & 0.132 \\
\hline Smoking history (\%) and pack-years & & & & 0.904 \\
\hline Never smoker & $35(67.3)$ & $23(69.7)$ & $12(63.2)$ & \\
\hline Ex-smoker, pack-years & $6(11.5), 17.7$ & $4(12.1), 19.4$ & $2(10.5), 14.3$ & \\
\hline Current smoker, pack-years & $11(21.2), 23.1$ & $6(18.2), 19.6$ & $5(26.3), 27.4$ & \\
\hline Pathologic stage & & & & 0.546 \\
\hline$\| \mathrm{B}$ & $3(5.8)$ & $1(3.0)$ & $2(10.5)$ & \\
\hline IV & $49(94.2)$ & $32(97.0)$ & $17(89.5)$ & \\
\hline \multicolumn{5}{|l|}{ Metastasis sites } \\
\hline Brain & $23(44.2)$ & $14(42.4)$ & $9(47.4)$ & 0.730 \\
\hline M1a sites & $28(53.8)$ & $22(66.7)^{*}$ & $6(31.6)$ & 0.015 \\
\hline M1b sites & $35(67.3)$ & $22(66.7)$ & $13(68.4)$ & 1.000 \\
\hline M1ab sites & $49(94.2)$ & $32(97.0)$ & $17(89.5)$ & 0.546 \\
\hline Death & $19(36.5)$ & $11(33.3)$ & $8(42.1)$ & 0.527 \\
\hline \multicolumn{5}{|l|}{ Histologic parameters } \\
\hline Presence of mucin & $10(22.7)$ & $5(17.2)$ & $5(33.3)$ & 0.271 \\
\hline Intracellular, columnar cells & $4(9.1)$ & $1(3.4)$ & $3(20.0)$ & 0.107 \\
\hline Intracellular, signet ring cells & $7(15.9)$ & $4(13.8)$ & $3(20.0)$ & 0.675 \\
\hline Extracellular & $4(9.1)$ & $1(3.4)$ & $3(20.0)$ & 0.107 \\
\hline Predominant pattern & & & & 0.443 \\
\hline Acinar & $15(38.5)$ & $8(33.3)$ & $7(46.7)$ & \\
\hline Solid & $18(46.2)$ & $11(45.8)$ & $7(46.7)$ & \\
\hline Cribriform & $4(10.3)$ & $4(16.7)$ & $0(0.0)$ & \\
\hline Micropapillary & $2(5.1)$ & $1(4.2)$ & $1(6.7)$ & \\
\hline Cribriform pattern & $10(22.7)$ & $7(24.1)$ & $3(20.0)$ & 1.000 \\
\hline Solid signet rings & $25(56.8)$ & $17(58.6)$ & $8(53.3)$ & 1.000 \\
\hline Prominent nucleoli & $17(38.7)$ & $14(48.2)$ & $3(20.0)$ & 0.136 \\
\hline Psammomatous calcification & $6(13.6)$ & $4(13.8)$ & $2(13.3)$ & 1.000 \\
\hline
\end{tabular}

* EML4-ALK variant 1 ( $N=13,65.0 \%)$; EML4-ALK variant $2(N=1,33.3 \%)$; EML4-ALK variant $3 a / b(N=8,80.0 \%)$

$A L K$ fusion variant was found in PFS of patients treated with crizotinib or ceritinib (Fig. 4). In the univariate Cox proportional hazards analyses for PFS on pemetrexed, v1 was determined to be a predictive factor for prolonged PFS, while non-EML4 was identified as a risk factor for shorter PFS. However, in the multivariate analysis, v1 was the only significant predictive factor of longer PFS (Table 3).

\section{Discussion}

In the present study, patients harboring the EML4$A L K$ variant, especially v1, had significantly prolonged PFS on pemetrexed therapy, whereas no difference in
PFS was observed for those treated with ALK inhibitors, according to the ALK fusion variants. Since FISH was used as the gold standard method for enrollment in clinical trials of ALK inhibitors, information on $A L K$ fusion variants was limited in previous studies, and the efficacy of chemotherapy or targeted therapy according to fusion variant was not established. In the present study, we confirmed the $A L K$ rearrangements in patient with NSCLCs using FISH and IHC and additionally specified the EML4-ALK variants using RT-PCR, which identifies the largest number of $E M L 4-A L K$ variants to date. 


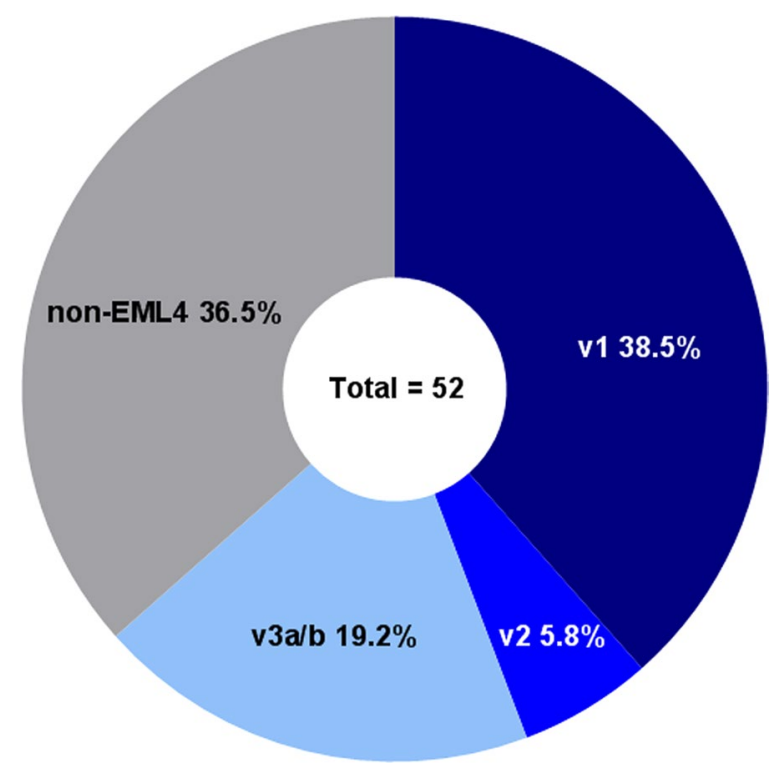

Fig. 1 Prevalence of ALK fusion variants

In the present study, EML4-ALK fusion v1 was the most common variant, identified in $38.5 \%$ of all patients and accounting for $60.6 \%$ of all EML4-ALK variants. This finding is consistent with previous studies $[15,16]$. Non$E M L 4$ variants were the second most common, identified in $36.5 \%$ of patients, which is slightly higher than that previously reported $[3,16]$. Although the RT-PCR methods used in the present study were designed to detect 28 types of EML4-ALK rearrangements, only v1, v2, and $\mathrm{v} 3 \mathrm{a} / \mathrm{b}$ were identified in our patients. Among the EML4$A L K$ variants, v3a/b and $\mathrm{v} 2$ were the second and third most common types, as previously described $[3,15]$.

Most of the patients in the present study received ALK inhibitors as second- or further-line treatment, and the ORR to ALK inhibitors was far better than to platinumbased or pemetrexed chemotherapy. Crizotinib was used most commonly, followed by ceritinib and alectinib. Crizotinib was initially developed as a c-Met inhibitor, but was found to be an efficient inhibitor of $A L K$ phosphorylation and signal transduction [17], and to be effective in the treatment of ROS1-rearranged NSCLCs $[18,19]$. Ceritinib $[20,21]$ and alectinib $[22,23]$ are second-generation ALK inhibitors that can be used in patients with crizotinib resistance or intolerance. In the present study, the treatment response rate to ALK inhibitors was no different between the EML4 group and non-EML4 group, consistent with a previous study [3]. There was also no difference among EML4-ALK variants. Recently, during preparation of our manuscript, Yoshida et al. reported on the frequency of $A L K$ fusion variants and the therapeutic efficacy of crizotinib according to the different variants in patients with $A L K$-rearranged NSCLCs; this approach was similar to that of our study [16]. They evaluated 35 patients with $A L K$-rearranged NSCLCs, and found that $\mathrm{v} 1$, the most common variant, was associated with superior PFS on crizotinib than non-v1 variants. This was not observed in our study. Further studies are required to investigate these discrepant findings. These two studies had similar limitations that could affect study results: both were retrospective studies with a small sample size. In addition, the treatment line for crizotinib differed across studies.

Although Yoshida et al. did not evaluate the therapeutic efficacy of second-generation ALK inhibitors such as ceritinib, we examined the therapeutic efficacy of ceritinib according to $A L K$ fusion variants, and found no difference in the use of ceritinib as crizotinib. Notably, however, one patient with v2 variant achieved a CR on ceritinib treatment. The tumor of this patient exhibited an extensive papillary and micropapillary pattern with partly retained alveolar wall architecture, distinguishing it histologically from the usual pattern of $A L K$-rearranged tumors. In the present study, all v2 patients showed PR to crizotinib and CR to ceritinib. Moreover, both the ORR and DCR were $100 \%$, although v2 was found in only 3 patients-too small a number to draw a general conclusion. A previous in vitro study reported v2 as being the most sensitive to $A L K$ inhibition, and explained that v2 has a shorter half-life compared with the other variants and is far more unstable since it has the longest $\mathrm{N}$-terminus of EML4 [24].

Pemetrexed, a folate antimetabolite that inhibits enzymes used in purine and pyrimidine synthesis, has been approved for malignant mesothelioma and NSCLC of non-squamous histology. Previous studies demonstrated an association between $A L K$ rearrangement in NSCLC and prolonged PFS in patients treated with pemetrexed $[25,26]$. The studies measured mRNA level of thymidylate synthase (TS), one of the catalytic enzymes thought to reduce sensitivity to pemetrexed, and showed a significantly lower TS mRNA level in $A L K$-rearranged tumor cells [26]. However, a more recent study with a larger cohort refuted these observations: it showed similar PFS of patients with $A L K$-rearranged and $A L K$-wild type NSCLCs [27]. They also measured mRNA level of TS and concluded that $A L K$ rearrangement was associated with a lower TS mRNA level, but that PFS on pemetrexed treatment was not affected by $A L K$ status 
Table 2 Efficacy of ALK inhibitors according to ALK fusion variants

\begin{tabular}{|c|c|c|c|c|c|c|}
\hline & Total $(N=52)$ & $\begin{array}{l}\text { EML4-ALK variant } 1 \\
(N=20)\end{array}$ & $\begin{array}{l}E M L 4-A L K \text { variant } 2 \\
(N=3)\end{array}$ & $\begin{array}{l}\text { EML4-ALK variant } \\
3 a / b(N=10)\end{array}$ & $\begin{array}{l}\text { Non-EML4 variants } \\
(N=19)\end{array}$ & $P$ value \\
\hline $\begin{array}{l}\text { First-line, platinum- } \\
\text { based CTx, } N(\%)\end{array}$ & $40(76.9)$ & $17(85.0)$ & $1(33.3)$ & $9(90.0)$ & $13(68.4)$ & 0.979 \\
\hline PR & $10(25.0)$ & $4(23.5)$ & $0(0.0)$ & $3(33.3)$ & $3(23.1)$ & \\
\hline SD & $20(50.0)$ & $9(52.9)$ & $1(100.0)$ & $4(44.4)$ & $6(46.2)$ & \\
\hline PD & $10(25.0)$ & $4(23.5)$ & $0(0.0)$ & $2(22.2)$ & $4(30.8)$ & \\
\hline ORR, \% & 25.0 & 23.5 & 0.0 & 33.3 & 23.1 & 0.853 \\
\hline DCR, \% & 75.0 & 76.5 & 100.0 & 77.8 & 69.2 & 0.791 \\
\hline $\begin{array}{l}\text { Received pemetrexed, } \\
\text { any line, } N(\%)\end{array}$ & $35(67.3)$ & $17(85.0)$ & $1(33.3)$ & $6(60.0)$ & $11(57.9)$ & 0.591 \\
\hline$P R$ & $7(20.0)$ & $2(11.8)$ & $0(0.0)$ & $3(50.0)$ & $2(18.2)$ & \\
\hline SD & $25(71.4)$ & $13(76.5)$ & $1(100.0)$ & $3(50.0)$ & $8(72.7)$ & \\
\hline PD & $3(8.6)$ & $2(11.8)$ & $0(0.0)$ & $0(0.0)$ & $1(9.1)$ & \\
\hline ORR, \% & 20.0 & 11.8 & 0.0 & 50.0 & 18.2 & 0.291 \\
\hline DCR, \% & 91.4 & 88.2 & 100.0 & 100.0 & 90.9 & 1.000 \\
\hline $\begin{array}{l}\text { Received Crizotinib, } \\
\quad N(\%)\end{array}$ & $32(61.5)$ & $10(50.0)$ & $2(66.7)$ & $8(80.0)$ & $12(63.2)$ & 0.134 \\
\hline PR & $17(53.1)$ & $3(30.0)$ & $2(100.0)$ & $4(50.0)$ & $8(66.7)$ & \\
\hline SD & $10(31.3)$ & $5(50.0)$ & $0(0.0)$ & $1(12.5)$ & $4(33.3)$ & \\
\hline PD & $5(15.6)$ & $2(20.0)$ & $0(0.0)$ & $3(37.5)$ & $0(0.0)$ & \\
\hline ORR, \% & 53.1 & 30.0 & 100.0 & 50.0 & 66.7 & 0.191 \\
\hline $\mathrm{DCR}, \%$ & 84.4 & 80.0 & 100.0 & 62.5 & 100.0 & 0.109 \\
\hline $\begin{array}{l}\text { Received Ceritinib, } \\
N(\%)\end{array}$ & $14(26.9)$ & $5(25.0)$ & $1(33.3)$ & $3(30.0)$ & $5(26.3)$ & 0.723 \\
\hline$C R$ & $1(7.1)$ & $0(0.0)$ & $1(100.0)$ & $0(0.0)$ & $0(0.0)$ & \\
\hline PR & $7(50.0)$ & $2(40.0)$ & $0(0.0)$ & $2(66.7)$ & $3(60.0)$ & \\
\hline SD & $4(28.6)$ & $2(40.0)$ & $0(0.0)$ & $1(33.3)$ & $1(20.0)$ & \\
\hline PD & $1(7.1)$ & $0(0.0)$ & $0(0.0)$ & $0(0.0)$ & $1(20.0)$ & \\
\hline ORR, \% & 57.1 & 50.0 & 100.0 & 66.7 & 62.5 & NA \\
\hline $\mathrm{DCR}, \%$ & 85.7 & 100.0 & 100.0 & 100.0 & 80.0 & NA \\
\hline $\begin{array}{l}\text { Received Alectinib, } \\
\quad N(\%)\end{array}$ & $2(3.8)$ & $0(0.0)$ & $0(0.0)$ & $1(10.0)$ & $1(5.3)$ & NA \\
\hline PR & $2(100.0)$ & $0(0.0)$ & $0(0.0)$ & $1(100.0)$ & $1(100.0)$ & \\
\hline
\end{tabular}

$C T x$ chemotherapy; $P R$ partial response; $S D$ stable disease; $P D$ progressive disease; $C R$ complete response; $O R R$ objective response rate; $D C R$ disease control rate; $N A$ not applicable

[27]. So far, all previous studies on pemetrexed efficacy confirmed $A L K$ rearrangement using the FISH method. Thus, frequency of $A L K$ fusion variants in each study was unknown [25-27]. One possible scenario for the observed discrepancy regarding pemetrexed efficacy is that proportion of v1 might have differed in each previous study, because in the present study pemetrexed showed a significantly better PFS when used to treat v1 variants than when used to treat other variants. Although we could not examine the TS level in tumors because the 

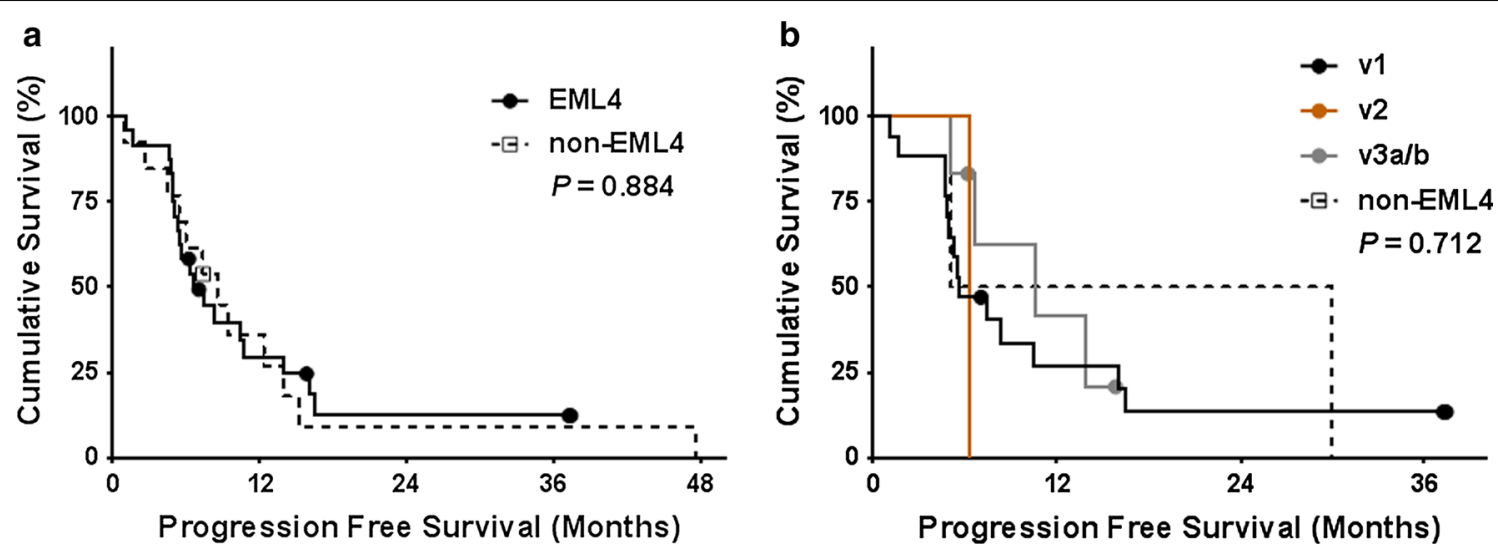

Fig. 2 Kaplan-Meier curves of progression free survival of patients treated with platinum-based chemotherapy, according to the ALK fusion variants. a $E M L 4(N=27)$ versus non-EML4 $(N=13)$. b Demonstration of progression free survival of each variant $(v 1, N=17 ; v 2, N=1 ; v 3 a / b, N=9$; non-EML4, N = 13). Each symbol on the plot marks a censored patient. v1, EML4-ALK variant 1; v2, EML4-ALK variant 2; v3a/b, EML4-ALK variant 3a/b
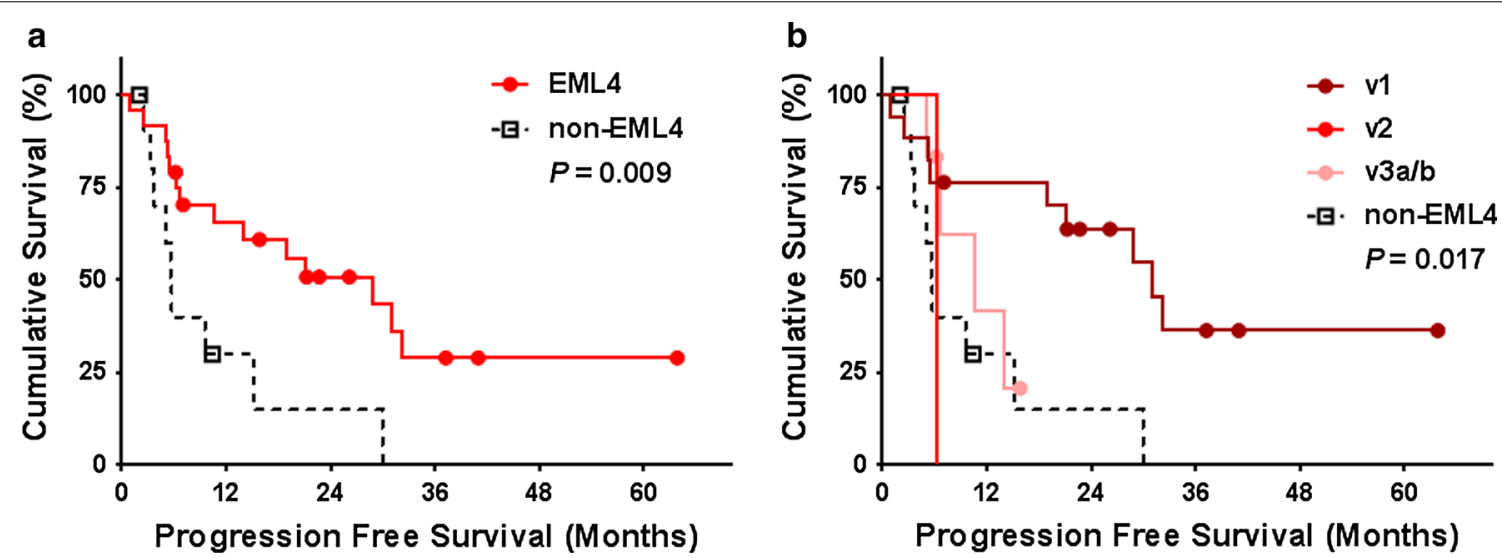

Fig. 3 Kaplan-Meier curves of progression free survival of patients treated with pemetrexed as any line, according to the ALK fusion variants. a EML4 $(N=24)$ versus non-EML4 ( $N=11)$. b Demonstration of progression free survival of each variant $(v 1, N=17 ; \mathrm{v} 2, N=1 ; \mathrm{v} 3 \mathrm{a} / \mathrm{b}, N=6 ; \mathrm{non}-$ EML4, $N=11$ ). Each symbol on the plot marks a censored patient. v1, EML4-ALK variant 1; v2, EML4-ALK variant 2; v3a/b, EML4-ALK variant 3a/b

remaining tumor tissue was not available due to previous extensive molecular examination, further validation is needed to clarify the mechanism of prolonged PFS of v1 on pemetrexed observed in the present study. Although crizotinib is the most efficient and verified target agent for patients with $A L K$-rearranged NSCLC, pemetrexed would be a good treatment option if patients harbor the v1 variant and cannot afford crizotinib. Subtyping $A L K$ variants might predict the efficacy of pemetrexed.

\section{Conclusions}

In conclusion, our study showed different PFS on pemetrexed treatment according to $A L K$ fusion variant in lung adenocarcinoma. $E M L 4-A L K$ variants, especially v1, had 

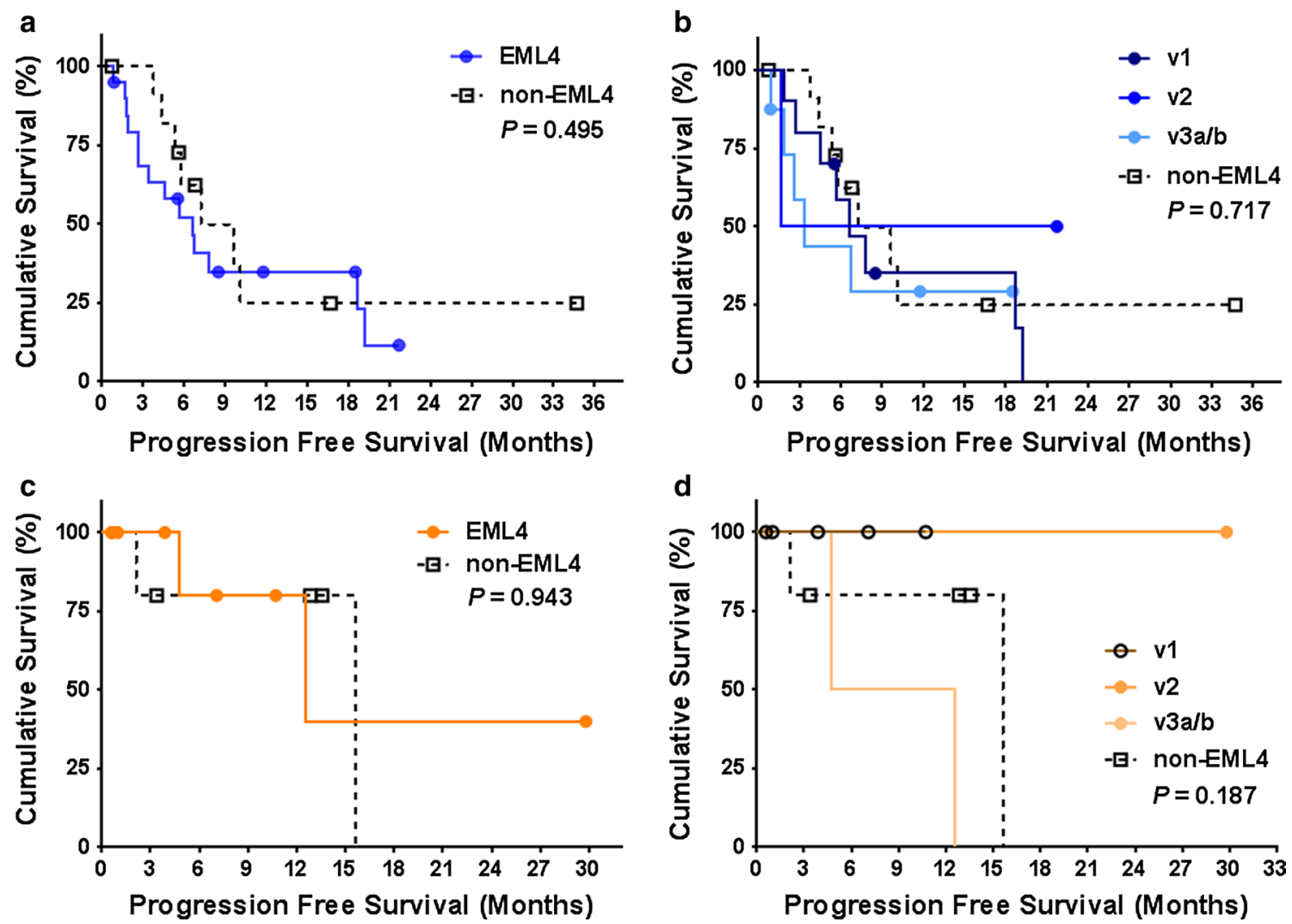

Fig. 4 Kaplan-Meier curves of progression free survival of patients treated with crizotinib and ceritinib according to the ALK fusion variants. a EML4 $(N=20)$ versus non-EML4 $(N=12)$ on crizotinib. b Demonstration of progression free survival of each variant $(v 1, N=10 ; v 2, N=2 ; v 3 a / b, N=8$; non-EML4, N=12) on crizotinib. c EML4 (N=9) versus non-EML4 $(N=5)$ on ceritinib. d Demonstration of progression free survival of each variant $(\mathrm{v} 1, N=5 ; \mathrm{v} 2, N=1 ; \mathrm{v} 3 \mathrm{a} / \mathrm{b}, N=3 ;$ non-EML4,N=5) on ceritinib. Each symbol on the plot marks a censored patient. v1, EML4-ALK variant 1; v2, EML4-ALK variant 2; $\mathrm{v} 3 \mathrm{a} / \mathrm{b}$, EML4-ALK variant $3 a / b$

Table 3 Cox proportional hazards regression analysis for progression free survival on pemetrexed

\begin{tabular}{|c|c|c|c|c|}
\hline \multirow[t]{2}{*}{ Variables } & \multicolumn{2}{|l|}{ Univariate } & \multicolumn{2}{|l|}{ Multivariate } \\
\hline & HR $(95 \%$ Cl) & $P$ value & HR (95 \% Cl) & $P$ value \\
\hline $\begin{array}{l}\text { EML4-ALK vari- } \\
\text { ant } 1\end{array}$ & $\begin{array}{l}0.262(0.098- \\
0.699)\end{array}$ & 0.007 & $\begin{array}{l}0.262(0.098- \\
0.699)\end{array}$ & 0.007 \\
\hline $\begin{array}{l}\text { EML4-ALK vari- } \\
\text { ant } 2\end{array}$ & $\begin{array}{l}2.364(0.305- \\
18.344)\end{array}$ & 0.410 & & \\
\hline $\begin{array}{l}\text { EML4-ALK variant } \\
3 a / b\end{array}$ & $\begin{array}{l}1.366(0.443- \\
4.214)\end{array}$ & 0.587 & & \\
\hline $\begin{array}{l}\text { Non-EML4 } \\
\text { variant }\end{array}$ & $\begin{array}{l}2.890(1.191- \\
7.013)\end{array}$ & 0.019 & & \\
\hline
\end{tabular}

Italic values indicate significance of $P$ value $(P<0.05)$

$H R$ hazard ratio; $\mathrm{Cl}$ confidence interval

superior PFS than the other variants. We found no difference in PFS with ALK inhibitors according to $A L K$ fusion variant. Further studies with large cohorts are required to confirm the different efficacy of pemetrexed or ALK inhibitors according to $A L K$ fusion variants.

\section{Additional file}

Additional file 1: Table S1. Metastatic sites according to ALK fusion variant. Table S2. Treatment history of patients before ALK inhibitors. Fig. S1. Histologic features of the tumor harboring EML4-ALK variant 2.

\begin{abstract}
Abbreviations
ALK: anaplastic lymphoma kinase; CR: complete response; Ct: threshold cycle; DCR: disease control rate; EGFR: epidermal growth factor receptor; EML4: echinoderm microtubule-associated protein-like 4; FFPE: formalin-fixed, paraffin-embedded; FISH: fluorescence in situ hybridization; IHC: immunohistochemistry; NSCLC: non-small cell lung cancer; ORR: objective response rate; PD: progressive disease; PFS: progression-free survival; PR: partial response; RT-PCR: real time-polymerase chain reaction; SD: stable disease; TKI: tyrosine kinase inhibitor; TS: thymidylate synthase.
\end{abstract}

\section{Authors' contributions}

YJC, HRK, and HSS, acquisition of data, analysis and interpretation of data; YJC and HSS, conception and design, writing the manuscript. All authors read and approved the final manuscript.

\section{Author details}

1 Department of Pathology, GangNam Severance Hospital, Yonsei University College of Medicine, Seoul, South Korea. ${ }^{2}$ Department of Oncology, Yonsei 
Cancer Center, Yonsei University College of Medicine, Seoul, South Korea. ${ }^{3}$ Department of Pathology, Severance Hospital, Yonsei University College of Medicine, 50-1 Yonsei-ro, Seodaemun-gu, Seoul 03722, South Korea.

\section{Acknowledgements}

The authors would like to thank PANAGENE for the excellent technical support.

\section{Competing interests}

The authors declare that they have no competing interests.

\section{Availability of data and material}

All data are available in the manuscript or upon request to the authors.

\section{Ethics approval and consent to participate}

This retrospective study was approved by the Institutional Review Board of Severance Hospital (No. 4-2015-0926).

\section{Funding}

This study was supported by the Basic Science Research Program through the National Research Foundation of Korea (NRF) funded by the Ministry of Science, ICT and Future Planning (NRF-2015R1C1A1A01051935).

Received: 15 September 2016 Accepted: 11 October 2016 Published online: 19 October 2016

\section{References}

1. Li T, Kung HJ, Mack PC, Gandara DR. Genotyping and genomic profiling of non-small-cell lung cancer: implications for current and future therapies. J Clin Oncol. 2013;31:1039-49.

2. Soda M, Choi YL, Enomoto M, Takada S, Yamashita Y, Ishikawa S, Fujiwara S, Watanabe H, Kurashina K, Hatanaka H, Bando M, Ohno S, Ishikawa Y, Aburatani H, Niki T, Sohara Y, Sugiyama Y, Mano H. Identification of the transforming EML4-ALK fusion gene in non-small-cell lung cancer. Nature. 2007:448:561-6.

3. Kwak EL, Bang YJ, Camidge DR, Shaw AT, Solomon B, Maki RG, Ou SH, Dezube BJ, Janne PA, Costa DB, Varella-Garcia M, Kim WH, Lynch TJ, Fidias P, Stubbs H, Engelman JA, Sequist LV, Tan W, Gandhi L, Mino-Kenudson M, Wei GC, Shreeve SM, Ratain MJ, Settleman J, Christensen JG, Haber DA, Wilner K, Salgia R, Shapiro GI, Clark JW, lafrate AJ. Anaplastic lymphoma kinase inhibition in non-small-cell lung cancer. N Engl J Med. 2010;363:1693-703.

4. Ou SH, Bazhenova L, Camidge DR, Solomon BJ, Herman J, Kain T, Bang YJ, Kwak EL, Shaw AT, Salgia R, Maki RG, Clark JW, Wilner KD, lafrate AJ. Rapid and dramatic radiographic and clinical response to an ALK inhibitor (crizotinib, PF02341066) in an ALK translocation-positive patient with non-small cell lung cancer. J Thorac Oncol. 2010;5:2044-6.

5. Takahashi T, Sonobe M, Kobayashi M, Yoshizawa A, Menju T, Nakayama E, Mino N, Iwakiri S, Sato K, Miyahara R, Okubo K, Manabe T, Date H. Clinicopathologic features of non-small-cell lung cancer with EML4-ALK fusion gene. Ann Surg Oncol. 2010;17:889-97.

6. Yoshida A, Tsuta K, Nakamura H, Kohno T, Takahashi F, Asamura H, Sekine I, Fukayama M, Shibata T, Furuta K, Tsuda H. Comprehensive histologic analysis of ALK-rearranged lung carcinomas. Am J Surg Pathol. 2011;35:1226-34.

7. Yoshida A, Tsuta K, Watanabe S, Sekine I, Fukayama M, Tsuda H, Furuta K, Shibata T. Frequent ALK rearrangement and TTF-1/p63 co-expression in lung adenocarcinoma with signet-ring cell component. Lung Cancer. 2011;72:309-15.

8. Li Y, Pan Y, Wang R, Sun Y, Hu H, Shen X, Lu Y, Shen L, Zhu X, Chen H. ALK-rearranged lung cancer in Chinese: a comprehensive assessment of clinicopathology, IHC, FISH and RT-PCR. PLOS ONE. 2013;8:e69016.

9. Kim H, Yoo SB, Choe JY, Paik JH, Xu X, Nitta H, Zhang W, Grogan TM, Lee $\mathrm{CT}$, Jheon $\mathrm{S}$, Chung $\mathrm{JH}$. Detection of ALK gene rearrangement in nonsmall cell lung cancer: a comparison of fluorescence in situ hybridization and chromogenic in situ hybridization with correlation of ALK protein expression. J Thorac Oncol. 2011;6:1359-66.
10. Hofman P, Ilie M, Hofman V, Roux S, Valent A, Bernheim A, Alifano M, Leroy-Ladurie F, Vaylet F, Rouquette I, Validire P, Beau-Faller M, Lacroix L, Soria JC, Fouret P. Immunohistochemistry to identify EGFR mutations or ALK rearrangements in patients with lung adenocarcinoma. Ann Oncol. 2012;23:1738-43.

11. Shaw AT, Kim DW, Nakagawa K, Seto T, Crino L, Ahn MJ, De Pas T, Besse B, Solomon BJ, Blackhall F, Wu YL, Thomas M, O'Byrne KJ, Moro-Sibilot D, Camidge DR, Mok T, Hirsh V, Riely GJ, lyer S, Tassell V, Polli A, Wilner KD, Janne PA. Crizotinib versus chemotherapy in advanced ALK-positive lung cancer. N Engl J Med. 2013;368:2385-94.

12. Camidge DR, Bang YJ, Kwak EL, lafrate AJ, Varella-Garcia M, Fox SB, Riely GJ, Solomon B, Ou SH, Kim DW, Salgia R, Fidias P, Engelman JA, Gandhi L, Janne PA, Costa DB, Shapiro Gl, Lorusso P, Ruffner K, Stephenson P, Tang Y, Wilner K, Clark JW, Shaw AT. Activity and safety of crizotinib in patients with ALK-positive non-small-cell lung cancer: updated results from a phase 1 study. Lancet Oncol. 2012;13:1011-9.

13. Eisenhauer EA, Therasse P, Bogaerts J, Schwartz LH, Sargent D, Ford R, Dancey J, Arbuck S, Gwyther S, Mooney M, Rubinstein L, Shankar L, Dodd L, Kaplan R, Lacombe D, Verweij J. New response evaluation criteria in solid tumours: revised RECIST guideline (version 1.1). Eur J Cancer. 2009;45:228-47.

14. Cha YJ, Lee JS, Kim HR, Lim SM, Cho BC, Lee CY, Shim HS. Screening of ROS1 rearrangements in lung adenocarcinoma by immunohistochemistry and comparison with ALK rearrangements. PLOS ONE. 2014;9:e103333.

15. Li T, Maus MK, Desai SJ, Beckett LA, Stephens C, Huang E, Hsiang J, Zeger G, Danenberg KD, Astrow SH, Gandara DR. Large-scale screening and molecular characterization of EML4-ALK fusion variants in archival nonsmall-cell lung cancer tumor specimens using quantitative reverse transcription polymerase chain reaction assays. J Thorac Oncol. 2014;9:18-25.

16. Yoshida T, Oya Y, Tanaka K, Shimizu J, Horio Y, Kuroda H, Sakao Y, Hida T, Yatabe Y. Differential crizotinib response duration among ALK fusion variants in ALK-positive non-small-cell lung cancer. J Clin Oncol. 2016:34:3383-9.

17. Christensen JG, Zou HY, Arango ME, Li Q, Lee JH, McDonnell SR, Yamazaki S, Alton GR, Mroczkowski B, Los G. Cytoreductive antitumor activity of PF-2341066, a novel inhibitor of anaplastic lymphoma kinase and c-Met, in experimental models of anaplastic large-cell lymphoma. Mol Cancer Ther. 2007:6:3314-22.

18. Rimkunas VM, Crosby KE, Li D, Hu Y, Kelly ME, Gu TL, Mack JS, Silver MR, Zhou X, Haack H. Analysis of receptor tyrosine kinase ROS1-positive tumors in non-small cell lung cancer: identification of a FIG-ROS1 fusion. Clin Cancer Res. 2012;18:4449-57.

19. Shaw AT, Ou SH, Bang YJ, Camidge DR, Solomon BJ, Salgia R, Riely GJ, Varella-Garcia M, Shapiro Gl, Costa DB, Doebele RC, Le LP, Zheng Z, Tan W, Stephenson P, Shreeve SM, Tye LM, Christensen JG, Wilner KD, Clark JW, lafrate AJ. Crizotinib in ROS1-rearranged non-small-cell lung cancer. N Engl J Med. 2014;371:1963-71.

20. Kim DW, Mehra R, Tan DS, Felip E, Chow LQ, Camidge DR, Vansteenkiste J, Sharma S, De Pas T, Riely GJ, Solomon BJ, Wolf J, Thomas M, Schuler M, Liu G, Santoro A, Sutradhar S, Li S, Szczudlo T, Yovine A, Shaw AT. Activity and safety of ceritinib in patients with ALK-rearranged non-small-cell lung cancer (ASCEND-1): updated results from the multicentre, open-label, phase 1 trial. Lancet Oncol. 2016;17:452-63.

21. Shaw AT, Kim DW, Mehra R, Tan DS, Felip E, Chow LQ, Camidge DR, Vansteenkiste J, Sharma S, De Pas T, Riely GJ, Solomon BJ, Wolf J, Thomas M, Schuler M, Liu G, Santoro A, Lau YY, Goldwasser M, Boral AL, Engelman JA. Ceritinib in ALK-rearranged non-small-cell lung cancer. N Engl J Med. 2014;370:1189-97.

22. Seto T, Kiura K, Nishio M, Nakagawa K, Maemondo M, Inoue A, Hida T, Yamamoto N, Yoshioka H, Harada M, Ohe Y, Nogami N, Takeuchi K, Shimada T, Tanaka T, Tamura T. CH5424802 (RO5424802) for patients with ALK-rearranged advanced non-small-cell lung cancer (AF-001.JP study): a single-arm, open-label, phase 1-2 study. Lancet Oncol. 2013;14:590-8.

23. Gadgeel SM, Gandhi L, Riely GJ, Chiappori AA, West HL, Azada MC, Morcos PN, Lee RM, Garcia L, Yu L, Boisserie F, Di Laurenzio L, Golding S, Sato J, Yokoyama S, Tanaka T, Ou SH. Safety and activity of alectinib against systemic disease and brain metastases in patients with crizotinibresistant ALK-rearranged non-small-cell lung cancer (AF-002JG): results from the dose-finding portion of a phase 1/2 study. Lancet Oncol. 2014;15:1119-28. 
24. Heuckmann JM, Balke-Want H, Malchers F, Peifer M, Sos ML, Koker M, Meder L, Lovly CM, Heukamp LC, Pao W, Kuppers R, Thomas RK. Differential protein stability and ALK inhibitor sensitivity of EML4-ALK fusion variants. Clin Cancer Res. 2012;18:4682-90.

25. Camidge DR, Kono SA, Lu X, Okuyama S, Baron AE, Oton AB, Davies AM, Varella-Garcia M, Franklin W, Doebele RC. Anaplastic lymphoma kinase gene rearrangements in non-small cell lung cancer are associated with prolonged progression-free survival on pemetrexed. J Thorac Oncol. 2011:6:774-80
26. Lee JO, Kim TM, Lee SH, Kim DW, Kim S, Jeon YK, Chung DH, Kim WH, Kim YT, Yang SC, Kim YW, Heo DS, Bang YJ. Anaplastic lymphoma kinase translocation: a predictive biomarker of pemetrexed in patients with nonsmall cell lung cancer. J Thorac Oncol. 2011;6:1474-80.

27. Shaw AT, Varghese AM, Solomon BJ, Costa DB, Novello S, Mino-Kenudson M, Awad MM, Engelman JA, Riely GJ, Monica V, Yeap BY, Scagliotti GV. Pemetrexed-based chemotherapy in patients with advanced, ALK-positive non-small cell lung cancer. Ann Oncol. 2013;24:59-66.

\section{Submit your next manuscript to BioMed Central and we will help you at every step:}

- We accept pre-submission inquiries

- Our selector tool helps you to find the most relevant journal

- We provide round the clock customer support

- Convenient online submission

- Thorough peer review

- Inclusion in PubMed and all major indexing services

- Maximum visibility for your research

Submit your manuscript at

www.biomedcentral.com/submit 